
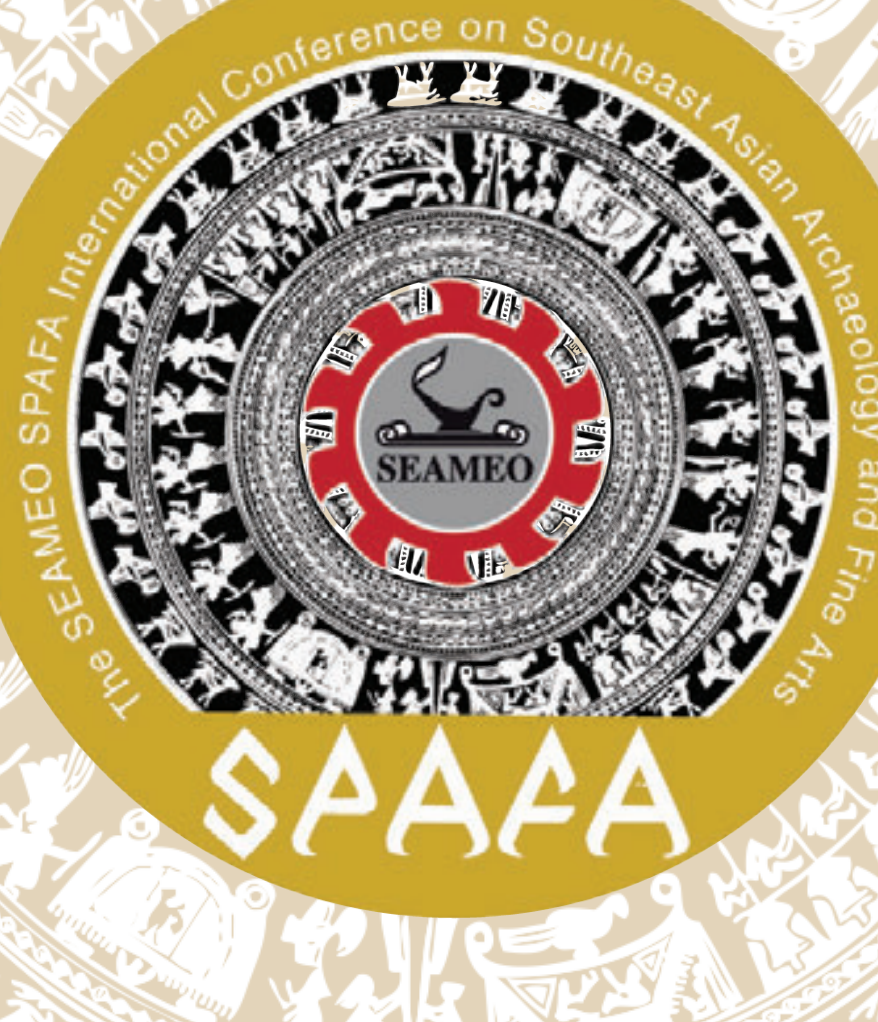
SPAFACON2021 is published by SEAMEO SPAFA, the Regional Centre for Archaeology and Fine Arts established by the Southeast Asian Ministers of Education Organization. SEAMEO SPAFA focusses on archaeology and fine arts in Southeast Asia, and promotes awareness and appreciation of the cultural heritage of the region. Its member-countries are Brunei, Cambodia, Indonesia, Lao PDR, Malaysia, Myanmar, the Philippines, Singapore, Thailand, Timor-Leste, and Vietnam; and its associate member-countries are Australia, Canada, France, Germany, the Netherlands, New Zealand, Spain and the United Kingdom. 


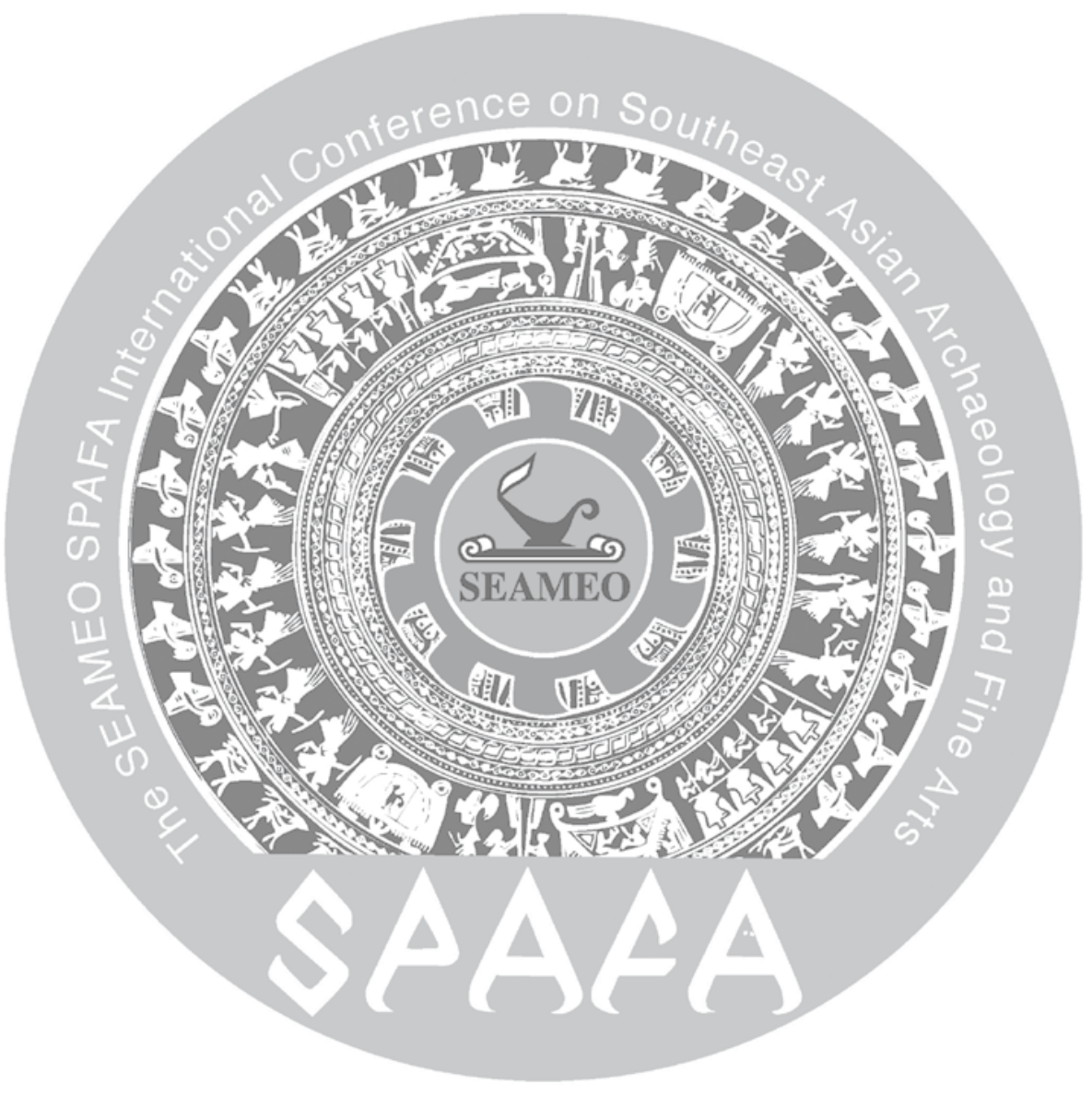

SPAFACON2021

Papers from the SEAMEO SPAFA International Conference on SOUTHEAST ASIAN ARCHAEOLOGY AND FINE ARTS

13 - 17 December 2021

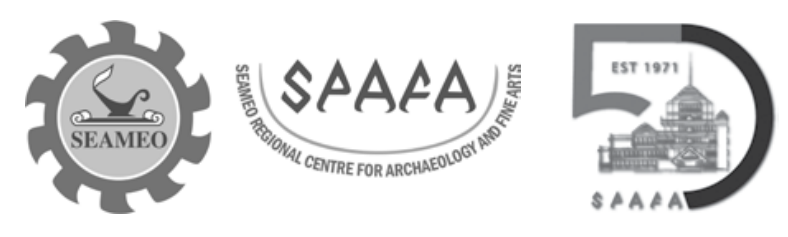


2021 SEAMEO SPAFA

ISBN: 978-616-7961-55-2

ISBN (e-book): 978-616-7961-54-5

DOI 10.26721/spafa.pqcnu8815a

\section{Publisher}

SEAMEO SPAFA Regional Centre for Archaeology and Fine Arts

81/1 Sri Ayutthaya Road, Dusit

Bangkok 10300, Thailand

Tel: +66 (0) 22804022 to 9

Fax: +66 (0) 22804030

www.seameo-spafa.org

E-mail: spafa@seameo-spafa.org

\section{Editor}

Dr Noel Hidalgo Tan

\section{Organizing Committee}

Mrs Somlak Charoenpot

Ms Vassana Kerdsupap

Mr Kanal Khiev

Mr Ean Lee

Ms Gabrielle Anne Mangaser

Dr Hatthaya Siriphatthanakun

Ms Ratchaporn Tesjeeb

Mr Patrick Xia Linhao

Dr Noel Hidalgo Tan

\section{(c) (1) (2)}

Copyright in the volume as a whole is vested in SEAMEO SPAFA, and copyright in the individual chapters also belong to their respective authors and licensed under Creative Commons CC BY-SA 4.0. To view a copy of this license, visit https://creativecommons. org/licenses/by-sa/4.0/

The papers in this publication have not been peer-reviewed and may thus contain preliminary findings, errors, or information that has yet to be endorsed by the relevant academic community. The views expressed in the publication do not necessarily reflect the opinions or policies of SEAMEO SPAFA. 


\section{Title}

\section{CONTENT}

\begin{tabular}{|c|c|c|}
\hline Title & Author & Page \\
\hline \multicolumn{3}{|l|}{ Introduction } \\
\hline $\begin{array}{l}\text { A Historiography of Settlement Archaeology in Southeast } \\
\text { Asia, with Emphasis on the Pre-industrial State Formations }\end{array}$ & Gyles Iannone & 1 \\
\hline $\begin{array}{l}\text { Ocean Imperatives: analysing shipping infrastructure for the } \\
\text { study of maritime networks in Southeast Asia }\end{array}$ & Veronica Walker Vadillo & 17 \\
\hline $\begin{array}{l}\text { Forms of government and local community participation in } \\
\text { the management of cultural World Heritage sites in Southeast } \\
\text { Asia }\end{array}$ & Vithaya Arporn & 24 \\
\hline $\begin{array}{l}\text { Cultural interaction between Việt Nam and Southeast Asian } \\
\text { nations in the } 15^{\text {th }}-16^{\text {th }} \text { centuries: An overview of pottery } \\
\text { items from ancient shipwrecks on display at the Museum of } \\
\text { History in Hồ Chí Minh City }\end{array}$ & $\begin{array}{l}\text { Phạm Ngọc Uyên, } \\
\text { Nguyễn Thị Tú Anh }\end{array}$ & 29 \\
\hline $\begin{array}{l}\text { Sequential Least-Cost Path Sailing Model for Early } 17^{\text {th }} \\
\text { Century South China Sea: Digitally Navigating the Selden } \\
\text { Map of China }\end{array}$ & Wesa Perttola & 40 \\
\hline $\begin{array}{l}\text { The Prevailing Art and Tradition of Intentional Dental } \\
\text { Modification in Prehistoric Southeast Asia }\end{array}$ & Maria Kathryn N. Purnell & 56 \\
\hline $\begin{array}{l}\text { The Still Unexplored Parts of Southeast Asian Archaeology: } \\
\text { Colonial Archaeology Singapore }\end{array}$ & Sxuann Sim & 74 \\
\hline $\begin{array}{l}\text { Khao San Dam: The Archaeological Evidence of Burnt Rice } \\
\text { Festival in Southern Thailand }\end{array}$ & Pakpadee Yukongdi & 83 \\
\hline $\begin{array}{l}\text { Before Bagan: Using Archaeological Data Sets to Assess the } \\
\text { Traditional Historical Narrative }\end{array}$ & $\begin{array}{l}\text { Scott Macrae, Gyles } \\
\text { Iannone, Kong Cheong, } \\
\text { Pyiet Phyo Kyaw }\end{array}$ & 96 \\
\hline The Rock Art in Kinta Valley, West Malaysia: A synthesis & $\begin{array}{l}\text { Chaw Yeh Saw } \\
\text { Hsiao Mei Goh }\end{array}$ & 114 \\
\hline $\begin{array}{l}\text { New Archaeological Discoveries: Gates and Turrets of } 16^{\text {th }} \\
\text { Burmese Royal Capital of Hamsāvatī }\end{array}$ & Thaw Zin Latt & 131 \\
\hline $\begin{array}{l}\text { A preliminary survey of Chinese ceramics in Champa } \\
\text { archaeological sites }\end{array}$ & Do Truong Giang & 148 \\
\hline $\begin{array}{l}\text { A Study on the Structure and Significance of the North } \\
\text { Sanctuary at Western Prasat Top }\end{array}$ & $\begin{array}{l}\text { SATO Yuni, TAMURA } \\
\text { Tomomi, SUGIYAMA } \\
\text { Hiroshi, LAM Sopheak, } \\
\text { SOK Keo Sovannara, } \\
\text { LOEUNG Ravattey, ROS } \\
\text { Visoth }\end{array}$ & 166 \\
\hline The funeral cave of Laang Spean & $\begin{array}{l}\text { Valéry Zeitoun, } \\
\text { Heng Sophady, Hubert } \\
\text { Forestier }\end{array}$ & 173 \\
\hline
\end{tabular}




\begin{tabular}{|c|c|c|}
\hline Title & Author & Page \\
\hline $\begin{array}{l}\text { The Bronze Age People of Ban Kao: A Preliminary Analysis } \\
\text { of the Human Remains from Ban Ta Po Archaeological Site, } \\
\text { Western Thailand }\end{array}$ & $\begin{array}{l}\text { Naruphol } \\
\text { Wangthongchaicharoen, } \\
\text { Supamas Duangsakul, } \\
\text { Pira Venunan, Sukanya } \\
\text { Lertwinitnun, Siriyupon } \\
\text { Tubpenthai }\end{array}$ & 187 \\
\hline The Mt. Popa Watershed and Bagan’s Bronze-Iron Age & Elizabeth Moore & 195 \\
\hline $\begin{array}{l}\text { After } 30 \text { Years and During a Pandemic: Pottery Production } \\
\text { and Distribution in Bagacay, Talibon in the Island of Bohol in } \\
\text { the Philippines }\end{array}$ & $\begin{array}{l}\text { Rhayan Gatbonton } \\
\text { Melendres }\end{array}$ & 205 \\
\hline $\begin{array}{l}\text { Heritage Education in Myanmar - developing resilience and } \\
\text { sustainability through community engagement }\end{array}$ & $\begin{array}{l}\text { Su Su, Win Thant Win } \\
\text { Shwin, Ohnmar Myo, } \\
\text { Charlotte Galloway, } \\
\text { Elizabeth Moore }\end{array}$ & 220 \\
\hline $\begin{array}{l}\text { As my father said: Traditional boatbuilding in Pasuruan, East } \\
\text { Java }\end{array}$ & $\begin{array}{l}\text { Agni Mochtar, Putri } \\
\text { Taniardi, R. Ahmad } \\
\text { Ginanjar Purnawibawa }\end{array}$ & 234 \\
\hline $\begin{array}{l}\text { Tangibility-Intangibility on UNESCO World Heritage } \\
\text { Baroque Philippine Churches: the Spirit of Place and Its } \\
\text { Collective Memory }\end{array}$ & Hee Sook Lee-Niinioja & 241 \\
\hline $\begin{array}{l}\text { Myinkaba village Bagan: The Resilience of Traditional } \\
\text { Knowledge and Culture }\end{array}$ & Theint Aung & 254 \\
\hline $\begin{array}{l}\text { Thai Carpentry Knowledge Transmission: Development of } \\
\text { Traditional Apprenticeships in a New Context }\end{array}$ & Nichamon Hiranpruek & 262 \\
\hline $\begin{array}{l}\text { The Factors of Market Success and Failure of Contemporary } \\
\text { Artists from ASEAN countries }\end{array}$ & Dr Rémy JARRY & 268 \\
\hline $\begin{array}{l}\text { The Forgotten Women: Investigating the Absence of the } \\
\text { Female Artist from Traditionally Male-Centric Southeast } \\
\text { Asian Contemporary Art Historical Narratives }\end{array}$ & Vasanth Narayanan & 279 \\
\hline As One With Nature: Southeast Asian Aesthetic Expressions & Victor R. Savage & 289 \\
\hline $\begin{array}{l}\text { The Series Of Archaeological Dances: A Historical Study and } \\
\text { Dance Moves Recording With Labanotation }\end{array}$ & Dharakorn Chandnasaro & 309 \\
\hline $\begin{array}{l}\text { Musical Instruments on the 16th century bas reliefs in } \\
\text { the North Gallery-East Wing of Angkor Wat : Dating and } \\
\text { Significance }\end{array}$ & Arsenio Nicolas & 324 \\
\hline $\begin{array}{l}\text { Photography in Indonesian Archaeology of the } 19^{\text {th }} \text { to the } \\
\text { Early } 20^{\text {th }} \text { Century }\end{array}$ & $\begin{array}{l}\text { Ahmad Kholdun Ibnu } \\
\text { Sholah }\end{array}$ & 356 \\
\hline $\begin{array}{l}\text { Old Burmese weights were not opium weights. They were } \\
\text { weights. What else do we know about them? }\end{array}$ & Bob Hudson & 369 \\
\hline $\begin{array}{l}\text { Religious Object" Exhibition in the Context of Cultural } \\
\text { Change and Covid-19 Social Distancing (Case studies of } \\
\text { Khmer's Nagar boat in the South of Vietnam) }\end{array}$ & Phạm Thị Thủy Chung & 381 \\
\hline
\end{tabular}




\section{Title}

Author

Page

Creativity and Innovation in Cultural Heritage Management in Plunturan Village, Pulung District, Ponorogo Regency,

Ria Kusuma Wardani, S.Pd.

East Java Province of Indonesia Towards Tourism Village

Beyond the artefact : promoting technology

Cécile de Francquen 407

Indonesian Museum after New Order Regime: The

Representation that Never Disappears

Ayu Dipta Kirana, Fajar

Aji Jiwandono

Geological Museum Innovations to Dealing with Covid-19 Ifan Yoga Pratama Suharyogi, Agustina Djafar, Rahajeng Ayu

Pandemic 


\section{INTRODUCTION}

This volume contains the extended abstracts from the papers presented at the SEAMEO SPAFA International Conference on Southeast Asian Archaeology and Fine Arts, which was held online from 13 to 17 December 2021. Also known as the SPAFACON2021, this conference was organised online due to the pandemic. Despite the disruption brought about by Covid-19 to our in-person events, training programmes and field research, it is heartening to see that archaeology and cultural heritage has continued under new modes of communication and collaboration.

This fourth iteration of the SPAFACON is also scheduled a year earlier than our usual triennial cycle to commemorate the 50th anniversary of SEAMEO initiating a centre dedicated towards archaeology and the fine arts. Over the past year, SPAFA has also been highlighting this legacy of international cooperation and capacity-building by sharing our photographic archives on our social media.

I am delighted by the high level of enthusiasm and intellectual curiosity brought by the participants to the conference. During our call for papers we received close to 90 submissions, but owing to the pressures of time and the online format, we were only able to accept 34 papers for the conference. The variety of papers present here, although a small set compared with our usual proceedings, reflects the breadth of the centre's ambit covering not just archaeology, but also performing arts, visual arts, museum studies, and other aspects of Southeast Asian cultural heritage.

I would like to thank all the participants, without whom this conference would not be possible in its present form, in particular, our Governing Board members who represent every country in Southeast Asia, and to the Ministry of Culture, Thailand and the Ministry of Education, Thailand for their long-standing support of SEAMEO SPAFA and its activities.

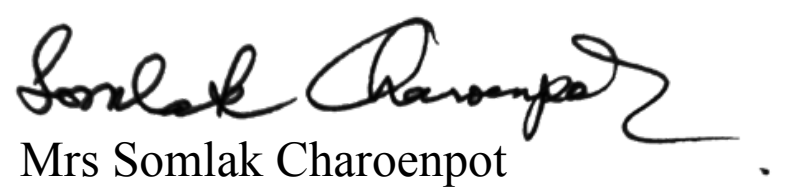

Centre Director

SEAMEO SPAFA 


\title{
The Forgotten Women: Investigating the Absence of the Female Artist from Traditionally Male-Centric Southeast Asian Contemporary Art Historical Narratives
}

10.26721/spafa.pqcnu8815a-24

Vasanth Narayanan

Stanford University

Stanford, California

\begin{abstract}
Until recently, Southeast Asian contemporary art's historical narratives overlooked the influence of female artists. This underrepresentation of female artists is not unique to Asia, nor is it exclusive to contemporary art. Curators' decisions and other factors may have contributed to the trend in part. However, within the realm of modern art, possibilities have lately developed that may expose the public to the work of more female artists. These include curating shows exclusively for female artists and prominently showcasing the work of female artists on the Internet.
\end{abstract}

\section{Keywords}

Southeast Asian; contemporary art; under-represented female artists; the curator; art galleries; art exhibitions; the Internet. 


\section{Introduction}

Contemporary art in Southeast Asia has a rich and colorful history that spans nine distinct areas (Singapore, the Philippines, Indonesia, Myanmar, Cambodia, Laos, Vietnam, Thailand, and Malaysia), each with its own distinct story. Whether via the infiltration of Roman Catholicism, Islam, Buddhism, or Hinduism, each has been subjected to the imposition of foreign religious ideals, and all except one-Thailand-have bore the patriarchal burden of European colonialism ("Thailand," 2017, item 4). Perhaps as a nod to the paternalistic approach, a defining feature of the present age in art has been dominance by male artists.

\section{The Southeast Asian History of Contemporary Art}

Southeast Asian painters trained at Chinese art academies and in Europe (mainly Paris) prior to the modern period. Following colonialism's fall, the freeing wave of postmodernism created an opportunity for bold-visioned artists to crack the egg of European influence on their work and create space for new contributions to Southeast Asian art's historical narrative. This began with the Nanyang style, which represented indigenous scenes and topics while successfully fusing Chinese painting traditions with western, mostly Parisian, art styles ("Nanyang Style" 2011).

The Nanyang Academy of Fine Arts in Singapore was formed in 1938 by four male painters who fell in love with the beauty of the local landscape after a historic trip to Bali. "The establishment of Society of Chinese Artists in 1935 had members who were not only alumni of Chinese art academies but were also avid fans of western art" ("Nanyang Style" 2011). The fusion of these two traditions into something new, with a focus on local subjects and occasionally a "art as activism" goal, resulted in the birth of an entirely new type of art.

Patrick Flores characterizes modern Southeast Asian artists as dynamic image makers, chroniclers of historical events, and occasional political commentators. He refers to the urge to "intensify an already ebullient post-colonialist drive. The effect is a vibrant, even baroque challenge to the totality of the dominant order that lies somewhere between ethnographic surrealism and everyday life" (Flores, n.d., Southeast Asia, final para.).

\section{The Perception of Male Artists' Work as More Important}

Since the early twentieth century, Southeast Asian men and women have produced creative work that has occasionally served as a vehicle for conveying social and political views. However, when it comes to establishing an individual artist's work as a legitimate 
component of a developing movement - that is, through placement in galleries and exhibits of Southeast Asian art - male-derived works have retained the majority of public attention. This is a disparity that art critics such as Maura Reilly have recognized and are attempting to address.

\section{The Curator's Role in the United States}

Maura Reilly links the comparatively limited exhibition of female artists in the United States to curatorial choices in her 2018 book, Curatorial Activism: Towards an Ethics of Curating. While females make up more than two-thirds of students enrolled in art and art history schools, Reilly notes that only one-third of artists whose work has been exhibited in US galleries are female (Reilly, 2018, "Introduction").

The "operative assumption" of Reilly's book, Curatorial Activism: Towards an Ethics of Curating, is that "the art system-its history, institutions, market, and press, and so forth - is a hegemony that privileges white male creativity to the exclusion of all other artists" (Reilly 2017, "What is Curatorial Activism?"). Reilly elucidates additional ways in which art history's exclusionary narratives are shaped: not only through the absence of one's work in galleries, but also through its exclusion from permanent collections and solo exhibition programs, as well as the factors of "auction-price differentials, and press coverage" (Reilly 2017, "What is Curatorial Activism?").

\section{Possible Explanations for Male Dominance}

Chaitanya Sambrani, a professor of Indonesian art history, observes that "the historiography of modernist and contemporary art in Indonesia has remained stubbornly male-dominated," which "is not an exclusively (or even Asian) quandary" (Sambrani 2020: 184). Sambrani suggests that their absence may be due to the overlooked successes of early female artists and the overshadowing of certain women's work by their spouses.

The historical causes for the absence of female artists differ per country. For example, a contemporary exhibition describes the role of the Vietnamese female artist as follows: "Still, today, living in a developing economy after decades of poverty and war, facing pressures of work, family life and male domination, women are often ignored in art exhibitions" (Changing Identity, n.d.). 


\section{Additional Justifications}

A longitudinal examination of art history reveals one probable explanation why painters of either gender have only recently emerged as significant figures in the evolution of Southeast Asian art. In Southeast Asia, the valued status of the European artist as a potentially significant figure in society has no equivalent. While Leonardo DaVinci and Michaelangelo had distinct personalities and were well-known throughout their respective eras, no such notoriety adhered in past centuries to the creators of master works of art in Southeast Asia.

Indeed, for hundreds of years, Southeast Asia's primarily male artists created the sculptures, paintings, and ornate architecture that defined their era. These individuals, who included nameless goldsmiths, silversmiths, stone carvers, and bronze craftsmen of their times, were largely artisans and monks committed to lifelong service (Dokras 2020: 145).

\section{Inclusion in Coursework and Anthologies of Students}

Given the multitude of factors that contribute to female absence, it's unsurprising that Southeast Asian female artists' work is almost invisible. When combined with the presence or absence of an artist's work in students' coursework and anthologies, both serve as markers of female artists' relative visibility in the historical narratives of contemporary art globally, but notably in Southeast Asia.

Author of Modern Art in Southeast Asia: Introductions from A to Z Paperback, Roger Nelson, writing from Singapore, speculates that if "artworks made by women, or by artists from minority populations, are less likely to be digitised or made available online," they are also less likely to be taught (Nelson 2020: 129).

Nora Taylor, a professor of Southeast Asian art at the School of the Art Institute of Chicago, is a frequent observer of "the issues that concern contemporary artists such as politics, gender and religion" (Taylor, 2020, p. 139). "As contemporary artists from Southeast Asia have received increased attention from art collectors, curators and museums around the world, I am able to include a greater variety of artists," she notes of her coursework (Taylor 2020: 139).

Taylor and Ly Boreth have edited a 2012 anthology titled Modern and Contemporary Southeast Asian Art. Taylor's commitment to advancing the work of female artists is evident in her curatorial work with International Arts and Artists on Changing Identity: Recent Work by Women Artists from Vietnam, 2007-2009, which she describes as "the 
first survey of women artists from Vietnam to tour the United States" (Taylor and Boreth 2012).

Deep S.E.A., an anthology curated by Primo Marella and published in 2013, contains 11 artists (one of them is a member of a man/woman pair). Only two of the eleven are female.

\section{Conscious Inclusion Efforts}

Author Greg Doyle makes an intentional reference to female artists in his description of the 9th Asia Pacific Triennial (APT) at the Queensland Art Gallery in 2018. "Indonesia is ably represented by five artists," he writes. "This relatively modest selection covers a lot of artistic ground. At a time when women are arguably under-represented in Indonesian art's international forays, it includes one female artist" (Doyle 2018: para. 2). Doyle is to be applauded, as an awareness of inequality is essential for future correction of such disparities.

\section{New Possibilities for Recognition}

Sotheby's will present the work of five female Southeast Asian painters in July 2020: Georgette Chen, Anita Magsaysay-Ho, Christine Ay Tjoe, Jane Lee, and Marina Cruz ("Five of the Most Influential").

Notably, Georgette Chen began teaching at the Nanyang Academy in 1954, becoming the only female member of the Nanyang Art Movement group. Chen's international experience aided her in defying established social conventions by portraying female nudity in an unprecedented manner. Although her paintings were frequently exhibited in European galleries, it was not until the mid-1950s that her work was recognized as part of Southeast Asian art's historical story (“Georgette Chen").

Similarly, to Georgette Chen's experience as the sole female member of a pioneering group of painters, Sotheby's notes that Filipino artist Anita Magsaysay-Ho was the sole female member of the group known as The Thirteen Moderns, which was renamed The Art Association of the Philippines in 1948. Her 1959 work, Washing of the Feet, was recently offered at Sotheby's. While the backdrop is biblical, the artist employs Filipino characters and imparts her own take on the historical deed shown, in which the messianic leader demonstrates his readiness to become "servant to all" (Mark 10:44).

Christine Ay Tjoe's art is one-of-a-kind. Sotheby's notes her extensive knowledge with a variety of drawing, painting, and sculpture techniques, as well as fabrics. In 2013's 
The Flying Balloon, her flamboyant use of color and sketches of everyday objects such as buttons, milk bottles, children's toys, frowny faces, and smiley faces-scattered across the canvas seemingly at random-promote an uplifting and expansive vision of the "everyday" as an appropriate artistic subject. This is indeed a revolutionary notion in comparison to earlier European still life paintings with bowls of fruit, flowers, and ceramics.

Jane Lee, a Singaporean artist, is another artist whose work has a distinct taste. According to Sotheby's, Lee is best known for her experiments with textured materials that serve as both media and subject matter in her work, whether they are coils of paper, each slightly different in texture from the ones around it; vibrantly colored oil paint squeezed out of a tube in layers that eventually resemble the folds of cloth; or any tangible substance that can engage the tactile senescence.

Sotheby's showcases the work of Filipino artist Marina Cruz, who paints and sculpts in the modern manner, as their final pick of five significant female artists. Cruz's pictures of women's and children's clothing transcend representationalism by their extreme focus on realistic details and assume a frightening realism as their torn textiles reflect the personalities of the individuals who formerly wore them.

\section{The Internet Expands Opportunities}

The advent of the Internet has increased the potential for artists to create artistic identities on a scale never seen before in Southeast Asia. Search engines connect viewers to artists' biographies and their most contentious works. The traditional "art show" can be replaced with something like Art Radar Journal's visual commemoration of International Women's Day-a photo essay titled "7 important women artists from Asia-Pacific" authored by Brittney (2014).

Even a prestigious auction house such as Sotheby's cannot match the impact of that 2014 Internet presentation, which included the work of Cambodian Anida Yoeu Ali, who fled Cambodia when she was five years old and whose unforgettable "Sarong Roots" depicts a woman leaning on a staircase and wearing a long, flowing dress made from sarongs obtained from other family members. "Sarong Roots" blends aspects of performance and installation, two popular contemporary art genres. "Weaving installation and performance, [Ali] creates work that investigates the artistic, spiritual and political collisions of a hybrid transnational and diasporic identity" (Brittney 2014). 
Readers who see the whole photo essay are invited to view videos of the many artists performing, which adds another dimension to the appreciation of their work.

\section{The Art Gorgeous}

Another very intriguing Internet product comes from The Art Gorgeous, which bills itself as "the most amusing newsletter in the art world." "15 Women at the Top of the Singapore Art Scene," written by Ning Chong, founder of The Culture Story, takes a detailed look at "the top women moving and shaking and making things happen for art in Singapore" (Chong 2019).

Two of the fifteen women on this list are curators. June Yap, for example, is dubbed "Singapore's most sought-after curator," and makes every effort to promote Southeast Asian art (Chong, 2019). 'Her modus operandi is 'build it and they will come,' meaning she produces exhibitions that are so good, people flock to see her work, rather than curating for the public." Adele Tan of the National Gallery Singapore is another curator who is a fan of performance art, photography, and new, innovative media. She has curated "some incredible shows, including co-curating the recent boundary-pushing exhibition “Awakenings: Art in Society in Asia 1960s-1990s"” (Chong 2019).

The show, according to a news release, was the conclusion of a five-year collaboration between three national museums in Japan, Korea, and Singapore, as well as the Japan Foundation Asia Center. It began in October 2018 in Japan and concluded a year later in Singapore. "This exhibition focuses, on an unprecedented scale, on the period from the 1960 s to the 1990 s, the dawning of contemporary art in Asian countries. It gathers together 140 provocative, experimental works produced in the turbulent period from more than ten regions and countries, and examines the similarities and differences between them" (Awakenings 2020).

Janice Wong and Polina Korobova, both of whom are renowned for their groundbreaking use of media, are among Chong's top female artists. Janice Wong's medium is confectionery. This pastry chef "conceives food as visual art. Janice has a two-pronged approach to her practice. First, she creates edible installations where she invites the audience to taste her creations. She exhibits tablescapes and even entire rooms made out of confectionary." Secondly, she has launched her own edible art supply line (Chong 2019). 
Polina Korobova, who was born in Russia and currently resides in Singapore, has an arresting appearance. By covering herself and her paintings in copious amounts of pink glitter, she imparts a "distinctly feminist flavor" to the local art ecology. Unsurprisingly, her performance piece is titled "Pink." "Polina's artwork aims to make a statement and show objects in a different light — a very sparkly, feminine light — to change people's perceptions, often with political and feminist undertones" (Chong 2019).

Tan Zi Xi and Kumari Nahappan are two painters whose work can only be characterized as "colossal." Tan Zi Xi, a professional illustrator, created a large-scale installation for the Singapore Art Museum in 2016. The project, titled "Plastic Ocean," dangled over 20,000 pieces of ocean debris in the air "to represent the waters the plastic waste was salvaged from and to remind us of the sheer volume of rubbish we generate" (Chong, 2019). Kumari Nahappan is credited for "putting Singaporean art into the global spotlight," alongside her husband, graffiti artist Cogtwo (Chong 2019). This artist makes works of art and sculptures that are larger than life in scale and can be found across the world, including enormous reproductions of chili peppers and other vegetables (Chong 2019).

Chong's portrayals of female artists and succinct descriptions of their work pique the imagination, allowing readers to see women as a dominant force in modern Southeast Asian art.

\section{Conclusion and Recommendations}

Perhaps the most effective method for resolving the issue of the invisible Southeast Asian woman artist would be to bring her work to the forefront in such a way that it cannot be ignored. The Internet, whether through provocative photo essays or ads for future exhibits, appears to be the right platform for doing this. By highlighting their work in this way, the role of female artists may be a source of inspiration for everyone. By collaborating, artists of both sexes may enjoy the chance to promote the cause of contemporary art in Southeast Asia - a region that is constantly evolving, constantly redefining itself.

\section{Acknowledgments}

I thank Nakesha Burr, Marisa Paine, and Yang Zi An for useful discussions regarding the contemporary presence of the female artist in different areas around the globe. 


\section{Bibliography}

Awakenings: Art in Society in Asia 1960s-1990s. (2020) Available at:

https://jfac.jp/en/culture/projects/p-awakenings/. [Accessed 16 Sep 2021].

Brittney (2014) 7 influential women artists from Asia-Pacific. Art Radar Journal, 3 Mar 2014. Available at: https://artradarjournal.com/2014/03/07/7-influential-womenartists-from-asia-pacific/. [Accessed $16 \mathrm{Sep} 2021$ ].

Changing Identity: Recent Work by Women Artists from Vietnam with International Arts and Artists, 2007-2009. (n. d.) Available at: https:crowcollection.org/ exhibition/changing- identity-recent-works-by-women-artists-from-vietnam/. [Accessed 8 Sep 2021].

Chong, N (2019). 15 Women at the Top of the Singapore Art Scene. The Art Gorgeous. 22 Nov 2019.

Dokras, U (2020). Scientific Borobudur. Stockholm: Indo-Nordic Author's Collective.

Five of the Most Influential Women Artists from Southeast Asia. Sotheby's, 2 July 2020. Flores, Patrick D. (2012) Southeast Asia: Art History, Art Today. Available at: https:// www.guggenheim.org/blogs/map/southeast-asia-art-history-art-today. [Accessed 13 Sept 2021].

Georgette Chen (2014) Singapore Women's Hall of Fame. Singapore: Singapore Council of Women's Organisations (SCWO).

Marella, P (ed.) (2013) Deep S.E.A.: Contemporary Art from South East Asia. Bologna: Damiani.

Nanyang Style - Singapore's Pioneer Art Movement (2011) Artyii News. Available at: https://www.mynewsdesk.com/sg/artyii/news/nanyang-style-singapore-spioneer-art-movement-25399 [Accessed 13 Sept 2021].

Nelson, R (2020a) Modern Art of Southeast Asia: Introductions from A to Z Paperback. Singapore: National Gallery Singapore.

Nelson, R (2020b) Some Questions on the Relationship between Institutions that Teach and Institutions that Exhibit, in Southeast Asia. Southeast of Now: Directions in Contemporary and Modern Art in Asia, 4(1): 125-130.

Reilly, M (2018) Curatorial Activism: Towards an Ethics of Curating. London: Thames \& Hudson.

Reilly, M (2017) What is Curatorial Activism? ARTNEWS. Available at: https:/www. academia.edu/38083139/What_Is_Curatorial_Activism [Accessed 8 Sep 2021]. 
Sambrani, C (2020) Art, Nation and World: Reflections on Teaching Indonesian Art in South-Eastern Australia. Southeast of Now: Directions in Contemporary and Modern Art in Asia, 4(1): 181 - 186.

Taylor, NA and Ly, B (eds.) (2012) Modern and Contemporary Southeast Asian Art: An Anthology. Ithaca, NY: Southeast Asia Program Publications.

Taylor, N (2020) Teaching Modern and Contemporary Southeast Asian Art in the US. Southeast of Now: Directions in Contemporary and Modern Art in Asia, 4(1): 137-140.

Thailand: Southeast Asia's Buffer Country. (2017) The Globalist. Available at: https://www.theglobalist.com/thailand-southeast-asias-buffer-country/ [Accessed 8 Sep 2021]. 